УДК 658.8

Дейнега I. О., д.е.н., доцент

Рівненський державний гуманітарний університет

\title{
РОЛЬ ФІРМОВИХ КОЛЬОРІВ В УПРАВЛІННІ БРЕНДАМИ ЗАКЛАДІВ ВИЩОЇ ОСВІТИ
}

\begin{abstract}
У статті актуалізовано значення кольору у маркетинговій діяльності організацій. Ідентифіковано вплив кольорів на емоційний стан людини. Розкрито культурні особливості сприйняття кольорів. Узагальнено практику найбільшого поширення кольорів і їх комбінації у брендингу вітчизняних i закордонних закладів вищої освіти. Розроблено практичні рекомендації щодо підбору закладом вищої освіти власних фірмових кольорів. Конкретизовано позиції законодавчого унормування вибору кольорів брендової символіки закладами вищої освіти.
\end{abstract}

Ключові слова: колір, фірмовий колір, органи чуття, бренд, брендова символіка, заклад вищої освіти.

Deineha I.

\section{THE ROLE OF BRAND COLORS IN THE MANAGEMENT OF BRANDS HIGHER EDUCATION INSTITUTIONS}

The article updates the value of color in the marketing activities of organizations. The influence of colors on the emotional state of a person has been identified. The cultural features of color perception are revealed. The practice of the largest distribution of colors and their combination in branding of domestic and foreign higher education institutions are generalized. Practical recommendations on the selection of institutions of higher education of their own corporate colors. The positions of legislative normalization of the choice of colors of brand symbolics by institutions of higher education are specified.

Key words: color, corporate color, sense organs, brand, brand symbolism, institution of higher education.

Дейнега И. А.

\section{РОЛЬ ФИРМЕННЫХ ЦВЕТОВ В УПРАВЛЕНИИ БРЕНДОМ УЧРЕЖДЕНИЙ ВЫСШЕГО ОБРАЗОВАНИЯ}

В статье актуализировано значение цвета в маркетинговой деятельности организаций. Идентифицировано влияние цвета на эмоциональное состояние человека. Раскрыто культурные особенности восприятия цветов. Обобщена практика наиболее распространенных цветов и их комбинаций в брендинге отечественных и зарубежных высших учебных заведений. Разработаны практические рекомендации по подбору заведением высшего образования собственных фирменных цветов. Конкретизированы позиции законодательного нормирования выбора цветов брендовой символики высшими учебными заведениями.

Ключевые слова: цвет, фирменный цвет, органы чувств, бренд, брендовая символика, учреждение высшего образования.

Постановка проблеми у загальному вигляді і її 3 важливими науковими та практичними завданнями. Бренд, як сукупність асоціацій, формується через систему матеріальних та нематеріальних складових. Споживачі сприймають їх через органи чуття, що, як відомо, забезпечують такі основні чутливості: види зір, слух, нюх, смак, дотик, рівновагу та відчуття положення тіла у просторі, тобто інформацію про товар вони сприймають не лише через систему зорової візуалізації, найбільшу питому вагу в якій займають семантичні конструкції. Колір, як суб'єктивна характеристика сприйняття світлової хвилі, може впливати на споживача, змінюючи його настрій, впливаючи на його вибір, формуючи систему асоціацій, з яких і складається бренд, тобто використання у бренді певних кольорів спрямоване на те, щоб викликати у споживача різні емоційні та/або поведінкові реакції. 
Заклади вищої освіти (ЗВО) поступово впроваджують у власну діяльність ринкові прийоми. Вони все більше приділяють увагу рекламі, масово проводять ребрендинг, змінюючи фірмові кольори та логотипи. Враховуючи також те, що люди різних вікових груп та психотипів надають перевагу різним кольорам, дослідження пріоритетних саме для цільової аудиторії ЗВО кольорів актуалізує дане дослідження.

Аналіз останніх досліджень, у яких започатковано вирішення проблеми. Роль кольору в житті людини детально розглянута в психології і педагогіці. Поширеним $\epsilon$ також обгрунтування ролі кольору у комерційній діяльності підприємства, зокрема у просуванні та стимулюванні збуту продукції чи послуг. Серед науковців, що займалися розкриттям змісту цього питання можна відзначити С. Махнушу, Н. Косолап, що досліджували проблеми формування бренд-колористики [1], Н. Скригун та ін., що вивчали особливості використання кольорової гами у харчовій промисловості [2], В. Божкову та Л. Носову, котрі оцінили значення кольору в рекламі [3], О. Дейнегу, який описав специфіку використання кольорів у комерційній діяльності промислових підприємств [4], М. Окландера, що проаналізував можливості врахування психологічного впливу кольору на поведінку споживачів [5]. Однак, практика застосування кольорів у маркетинговій діяльності 3ВО досліджена не достатньо.

Цілі статті. Метою написання статті $\epsilon$ визначення ролі кольорів бренду у діяльності ЗВО та розробка практичних рекомендацій щодо їх бренд-колористики.

Виклад основного матеріалу дослідження 3 повним обгрунтуванням отриманих наукових результатів. Фірмові кольори $\epsilon$ надзвичайно важливим інструментом, фоном товарного знака серед подібних або майже тотожних об'єктів. В історії ті або інші кольори в поданні суспільства пов'язувалися із якимись конкретними якостями чи подіями. Наприклад, «білий є кольором чистоти; чорний - розкоші; синій лідера; пурпурний - обраності; зелений - навколишньої природи і здоров'я» [6, с. 53]. Вибираючи колір для бренду чи логотипу, менеджери організацій повинні враховувати емоційний стан, який вони хочуть сформувати у споживача, а також те, який зміст закладається у філософію діяльності самої організації.

Колір - це теж інформація, яка закодована за допомогою системи хвиль певної довжини і сприймається контактною аудиторією організації через очі та шкіру. Використання правильно підібраної кольорової гами дозволяє «привабити увагу і сформувати образ організації через психологічний вплив на людей» [7, с. 370]. Н. Плішко застосовує термін «колірні переваги», які, на його думку, мають непрямий стосунок до питання про енергетичний вплив кольору на центральну нервову систему [8].

Загальноприйняті вимоги по підбору кольорів при формуванні брендів товарів, можуть бути застосовані і по відношенню до ЗВО. В першу чергу це стосується вимоги, коли бренд повинен враховувати специфіку діяльності організації, підкреслювати іiі конкурентні переваги (зокрема, якщо це ЗВО 3 «історією» варто використовувати коричневий колір, а коли він орієнтований на екологічну компоненту - зелений, на водні ресурси - синій або блакитний тощо).

При підборі кольорів або їх кольорової гамми, що будуть використані в бренді, необхідно враховувати певні закономірності. Слід зазначити, що в умовах кризи використання насичених, глибоких кольорів, таких як, наприклад, червоний, чорний, насичені фіолетовий і жовтий тощо, необхідно обмежити. Вони повинні застосовуватися виключно для того, щоб підкреслити інші кольори. При цьому перевагу варто надати світлим природнім кольорам, які будуть навіювати оточуючим оптимізм і спокій. Особливо це стосується вибору кольорів для брендової символіки організації (табл. 1). 
Таблиця 1

Вплив кольору на емоційний стан споживача

\begin{tabular}{|c|c|}
\hline Колір & Оцінка \\
\hline Білий & $\begin{array}{l}\text { Нейтральний. Як правило, служить фоном, на якому будь-яка інформація } \\
\text { сприймається легко. Майже ніколи не викликає негативних асоціацій. } \\
\text { Пов'язаний з чистотою, молодістю і світлом. }\end{array}$ \\
\hline Чорний & $\begin{array}{l}\text { Може викликати депресію у потенційних споживачів, проте чорні шрифти } \\
\text { виглядають цілком доречними і традиційними. Символ солідності і високої } \\
\text { якості. Пов'язаний із нічним часом, таємницею і сумом. }\end{array}$ \\
\hline Фіолето-вий & $\begin{array}{l}\text { Сприяє прийняттю креативних рішень. Колір абстракції і внутрішньої } \\
\text { концентрації, популярний серед творчих людей. Передає мудрість, артистизм, } \\
\text { натхнення, благородство і таємницю. Підходить для реклами ЗВО, що хочуть } \\
\text { підкреслити творчу складову. }\end{array}$ \\
\hline Синій & $\begin{array}{l}\text { Заспокоює, налаштовує споживача на раціональне прийняття рішень, і не } \\
\text { викликає негативних емоцій. Один із кращих кольорів, що привертають увагу. } \\
\text { Основні асоціації - мир, спокій, глибина, мудрість, тиша. }\end{array}$ \\
\hline Блакитний & $\begin{array}{l}\text { Колір інтелекту і гармонії. Семантика світло-блакитного: лід, холод, чистота, } \\
\text { щирість і байдужість. }\end{array}$ \\
\hline Зелений & $\begin{array}{l}\text { Може забезпечити цілющі і розслаблюючі ефекти. Символізує життя, природу, } \\
\text { гармонію, природність, розвиток, доброту. }\end{array}$ \\
\hline Жовтий & $\begin{array}{l}\text { Може зробити рекламований продукт «розумним» і допомогти поглинути нові } \\
\text { ідеї. Семантика жовтого: сонце, свято, радість, свобода, достаток. }\end{array}$ \\
\hline $\begin{array}{l}\text { Помаран- } \\
\text { чевий }\end{array}$ & $\begin{array}{l}\text { Викликає сплеск життєвої енергії і захищає споживача від негативного впливу } \\
\text { зовнішніх факторів. Активізує процес прийняття рішень. Може } \\
\text { використовуватись на рекламних матеріалах 3ВО. Асоціації: рух, товариськість, } \\
\text { бадьорість, швидкість. }\end{array}$ \\
\hline Червоний & $\begin{array}{l}\text { Стимулює споживача приймати негайні рішення і здійснювати необачні дії, } \\
\text { тому він типовий для реклами. Однак, варто використовувати в помірних } \\
\text { кількостях, тому що надлишок цього кольору може викликати роздратування і } \\
\text { агресію. Семантика червоного: пристрасть, життя, воля, боротьба, активність i } \\
\text { вогонь. }\end{array}$ \\
\hline
\end{tabular}

При підборі кольорів для брендової символіки ЗВО, який орієнтований на просування своєї присутності на глобальному ринку освітніх послуг, варто також враховувати і культурні аспекти їх сприйняття цільовою аудиторією (табл. 2). У різних народів один і той самий колір може викликати різні емоції та асоціації, що пов’язано із відмінностями у традиціях і віруваннях. Наприклад, білий колір в країнах Свропи і в тому числі в Україні характеризує невинність і чистоту, пов'язаний із позитивними емоціями (весілля, шлюб), тоді як в Китаї, Японії, Індії цей колір має негативний відтінок, оскільки асоціюється $з$ трауром і нещастям, що обмежує його застосування у брендингу 3ВО та інших складових комплексу маркетингових комунікацій при прийнятті рішення про освоєння цих цільових ринків.

Таблиця 2

Культурні особливості сприйняття кольорів

\begin{tabular}{|c|c|}
\hline Колір & Аспект об’єктної ідентифікації \\
\hline Білий & $\begin{array}{l}\text { Свропа: шлюб, ангели, лікарі, лікарня, світ; Японія: траур, біла гвоздика } \\
\text { символізує смерть; Китай: траур, смерть; Індія: нещастя; Схід: похорон; Фен-- } \\
\text { шуй: Янь, метал, смерть, примари, траур, рівновага, впевненість; Київська Русь: } \\
\text { вічна безмовність. }\end{array}$ \\
\hline Чорний & $\begin{array}{l}\text { Свропа: траур, похорон, смерть, бунт, спокій; Таїланд: нещастя, зло; } \\
\text { Іудаїзм: нещастя, зло; Австралійські аборигени: колір людей; Фен-шуй: нь, } \\
\text { вода, гроші, успіх в кар'єрі, дохід, стабільність, емоційна захист, сила; Київська } \\
\text { Русь: кінець, смерть, пекло. }\end{array}$ \\
\hline
\end{tabular}




\begin{tabular}{|c|c|}
\hline & 0 \\
\hline 1 & 2 \\
\hline Фіолетовий & $\begin{array}{l}\text { Таїланд: траур (вдови); Католицизм: смерть, траур, розп'яття; Фен-шуй: Інь, } \\
\text { колір фізичного і психічного зцілення. }\end{array}$ \\
\hline Синій & $\begin{array}{l}\text { Значення символіки кольору близьке до блакитного; Київська Русь: таємниця, } \\
\text { небо, духовність. }\end{array}$ \\
\hline Блакитң & $\begin{array}{l}\text { Європа: заспокоєння; Іран: траур, колір неба і духовність; Китай: безсмертя; } \\
\text { Індуїм: колір Крішни; Іудаїзм: святість; Християнство: колір Христа; } \\
\text { Католицизм: кольору одягу Марії; Близький Схід: захист; глобальне } \\
\text { сприйняття: колір безпеки; Фен-шуй: Інь, вода, спокій, любов, зцілення, } \\
\text { релаксація, довіру, пригоди; Захід: печаль, депресія; Київська Русь: юність, } \\
\text { матеріальний світ. }\end{array}$ \\
\hline Зелений & $\begin{array}{l}\text { Японія: життя; Іслам: надія, чеснота; Ірландія: символ всієї країни; Свропа / } \\
\text { США: весна, нове народження, День Святого Патрика, Різдво (з червоним); } \\
\text { США: гроші (бакси); Індія: Іслам; Фен-шуй: Інь, дерево, зцілення, здоров'я, } \\
\text { спокій. }\end{array}$ \\
\hline Жовтий & $\begin{array}{l}\text { Європа: щастя, надія, радість, боязнь небезпек, слабкість; Азія: колір } \\
\text { імперського; Сгипет: траур; Японія: мужність; Індія: торговці; Буддизм: } \\
\text { мудрість; Фен-шуй: Янь, Земля, сприятливий, сонячні промені, тепло, рух; } \\
\text { Київська Русь: сонце. }\end{array}$ \\
\hline $\begin{array}{c}\text { Помаранче- } \\
\text { вий }\end{array}$ & $\begin{array}{l}\text { Свропа: осінь, урожай, творчість; Ірландія: протестанти (релігійні); США: } \\
\text { Хеллоуїн (3 чорним), дешеві товари; Індуїзм: шафран (персиковий } \\
\text { помаранчевий) священний колір; Фен-шуй: Янь, Земля, цілі, підсилює } \\
\text { концентрацію. }\end{array}$ \\
\hline Червоний & $\begin{array}{l}\text { Китай: колір нареченої, удачі, торжества; Індія: чистота; Південна Африка: } \\
\text { траур; Схід: радість (в поєднанні з білим); Захід: збудження, любов, пристрасть; } \\
\text { США: Різдво (у поєднанні з зеленим), День святого Валентина (з білим); Іврит: } \\
\text { жертва, гріх; Японія: життя; Християнство: жертва, пристрасть, любов; Фен- } \\
\text { шуй: Янь, вогонь, удача, повага, захист, живучість, гроші, визнання; Київська } \\
\text { Русь: краса, радість, життя. }\end{array}$ \\
\hline
\end{tabular}

Джерело: напращювання власне на підставі [10]

При виході на міжнародний освітній простір варто враховувати також те, що у різних культурах кольори можуть мати різні значення. Збалансоване використання кольору привертає потенційного споживача, створює сприятливу атмосферу, заспокоює і полегшує сприйняття інформації. Колір значно впливає на емоційний стан людей i їх почуття, викликає підсвідомі асоціації.

Таким чином, при підборі кольорів брендової символіки ЗВО необхідно керуватися такими рекомендаціями:

- відповідність специфіці цільової аудиторії, на задоволення потреб якої націлена діяльність 3ВО;

- відображення філософії діяльності ЗВО, змісту його ідей, історії та стратегії розвитку тощо, тобто не заперечувати, а підсилювати базові цінності, на яких грунтується діяльність 3ВО;

- забезпечення взаємозв'язку кольору із іншими складовими брендової символіки 3ВО, зокрема логотипом і слоганом;

- відмова від наслідування «ідеальної» колірної гами успішних на ринку 3ВО, варто знайти свій, відмінний від інших стиль [7, с. 373].

Результати дослідження кольорової гами брендової символіки ЗВО України, дозволяють констатувати, що при їі формуванні застосовуються переважно білий (173 3ВО), жовтий (172 3ВО), блакитний (133 3ВО), синій (109 3ВО), червоний (91 3ВО), чорний (50 3ВО), зелений (53 3ВО) та сірий (41 3ВО) кольори (рис. 1). 


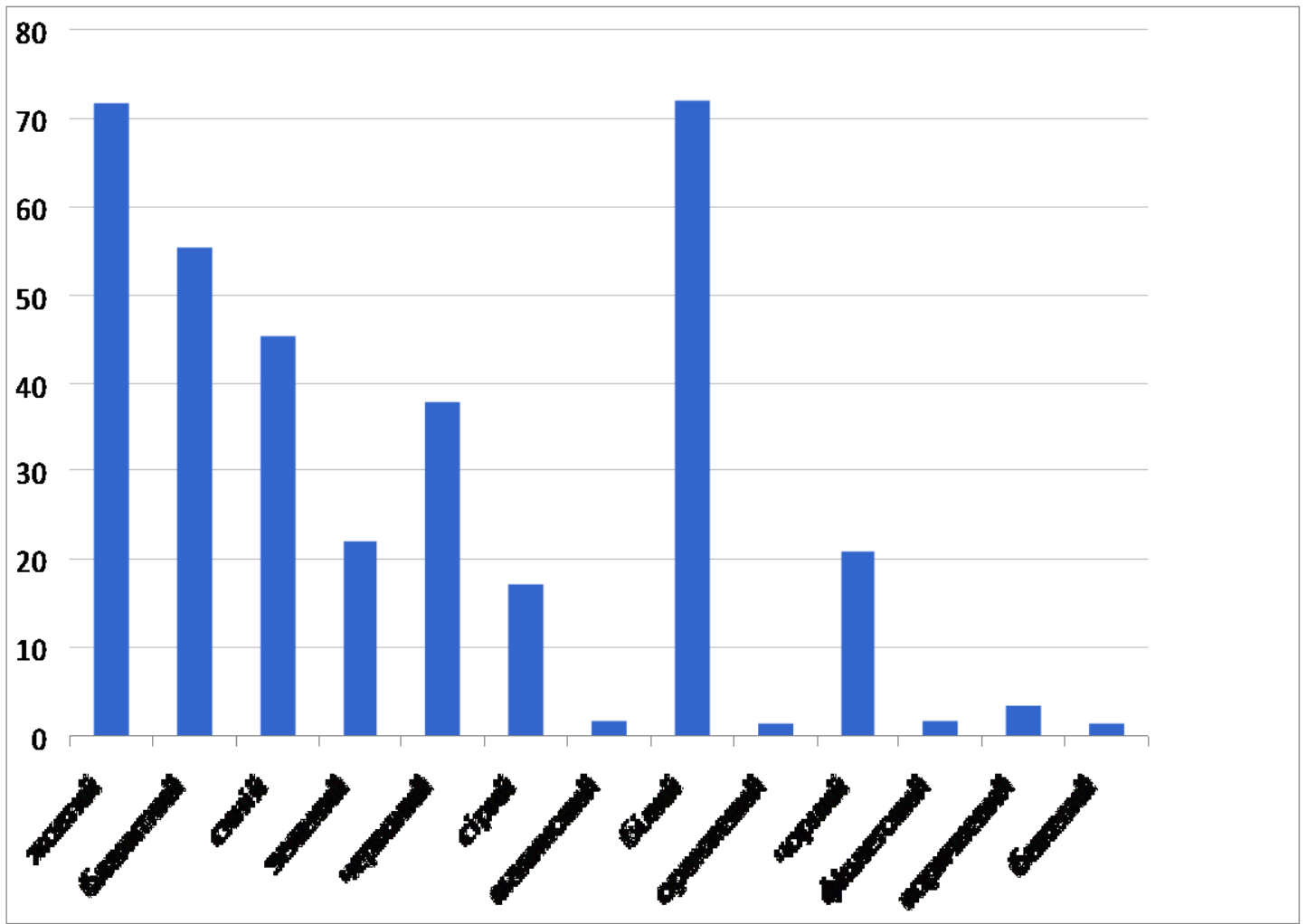

Рис. 1. Вагомість застосування кольорів у брендовій символіці вітчизняних 3ВО,

Джерело: власне напраџювання [11, с. 175]

Переважна більшість ЗВО використовує білий колір або для фону зображення, або як колір написання букв. У рідких випадках білий колір використовується як колір зображення. Так само не часто для таких цілей ЗВО використовують і чорний колір. Переважно він $є$ кольором букв і лише у деяких випадках - вагомою частиною забарвлення логотипу. Надають перевагу чорному обрамленню ЗВО, які перебувають у підпорядкуванні Міністерства внутрішніх справ. Цей колір є найбільш «важким» для сприйняття, у даному контексті символізує силу і владу. Крім того такі ЗВО часто застосовують сірий колір як символ зброї.

Значна кількість відтінків брендової символіки вітчизняних ЗВО і червоного кольору: від світло-червоного до насиченого червоного, майже бордового. При цьому цей колір використовується як базовий або формує акцент на дрібних деталях. Ним переважно забарвлюють символічне зображення «вогню знань».

Найбільше різних відтінків у брендовій символіці ЗВО має жовтий колір - від світло-жовтого до насиченого золотавого відтінку. Золотавий відтінок у брендах застосовується переважно для зображення колосків (символу родючості і достатку), а також на гербах ЗВО Міністерства фінансів як символ золота (добробуту і процвітання).

Велика кількість 3ВО (понад 50\%) застосовує у своїй брендовій символіці чотири і більше кольорів і лише четверта частина 3 них - один або два $(24,6 \%)$ (рис. 2). Слід зазначити, що найкращі ЗВО світу переважно використовують обмежену палітру кольорів, надаючи перевагу червоному та синьому. 

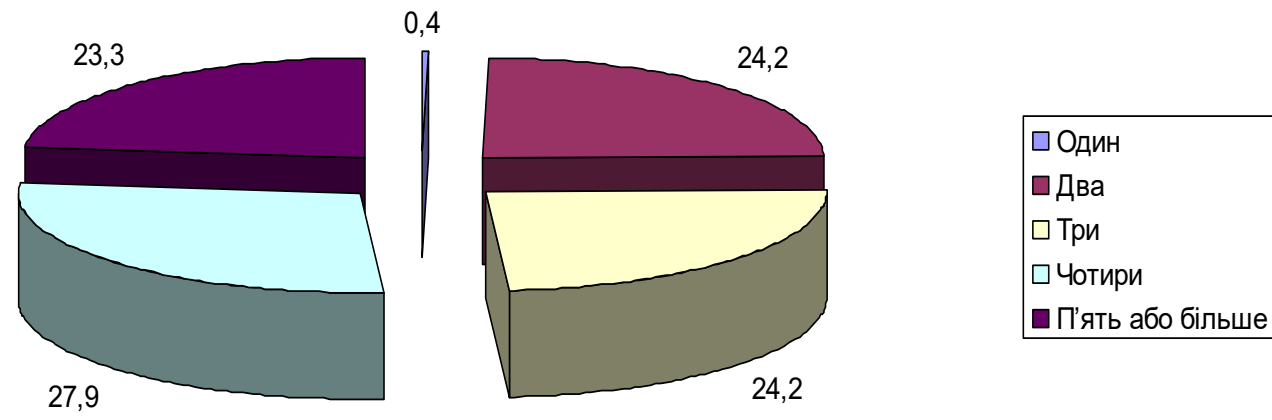

Рис. 2. Частота застосування комбінацій кольорів у брендовій символіці вітчизняних $3 \mathrm{BO}, \%$

Джерело: власне напраџювання [11, с. 176]

Законодавство України не перешкоджає творчості освітніх організацій при створенні ними бренду. Зокрема, в ЗУ «Про освіту» присутній термін «універсальний дизайн у сфері освіти», яким передбачається «дизайн предметів, навколишнього середовища, освітніх програм та послуг, що забезпечує їх максимальну придатність для використання всіма особами без необхідної адаптації чи спеціального дизайну» [12].

Для підбору кольорів сайту практики у сфері дизайну пропонують застосовувати основні принципи теорії кольору, які основуються на застосуванні кругу кольорів, винайденого І. Ньютоном у 1666 р. Саме ця теорія лягла в основу становлення і розвитку сучасної оптики, складовою частиною якої $\epsilon$ web-дизайн. I. Ньютон за допомогою тригранної скляної призми розклав біле світло на сім кольорів (в спектр), довівши його складність (явище дисперсії), відкрив хроматичну аберацію. Круг кольорів дозволяє вибрати оптимальне поєднання кольорів, які б гармонували разом. Для цього необхідно використовувати будь-які два кольори один навпроти одного, будь-які три кольори на рівній відстані при формуванні трикутника або будь-який з чотирьох кольорів, що утворюють прямокутник (дві пари кольору один навпроти одного). Схеми залишаються правильними незалежно від кута повороту [13].

Висновки. Отже, колір відіграє значну роль при ідентифікуванні бренду 3ВО, дозволяє цільовій аудиторії краще визначити концепцію 3ВО, систему його цінностей, сформувати стійку систему асоціацій по відношенню до нього. При підборі кольорів бренду ЗВО повинні в першу чергу враховувати специфіку своїх освітніх продуктів і характеристики цільової аудиторії. Дослідження встановило, що вітчизняні ЗВО застосовують для реалізації цієї комунікаційної складової переважно білий, жовтий, блакитний та синій кольори, причому більше половини поєднують у своїх брендах чотири i більше кольори. На противагу їм найкращі $3 \mathrm{BO}$ світу переважно використовують обмежену палітру кольорів, надаючи перевагу червоному та синьому.

\section{Список бібліографічного опису:}

1.Махнуша С. М., Косолап Н. С. Аналіз бренд-колористики як інструменту впливу на цільову аудиторію бренда. Маркетинг і менеджмент інновачій. 2011. № 2. С. 95-104.

2.Скригун Н. П., Семененко К. Ю., Білодідова Н. М. Кольорова гама в оформленні упаковки пивної продукції як ключовий засіб комунікацій зі споживачем. Науковий вісник Херсонського державного університету. Сер. : Економічні науки. 2016. Вип. 20(2). С. 101-104.

3.Божкова В. В., Носонова Л. В. Роль поліграфічної реклами у просуванні продукції машинобудівних підприємств. Науковий вісник Ужгородського національного університету. Серія : Міжнародні економічні відносини та світове господарство. 2017. Вип. 14(1). С. 31-36. 
4.Дейнега О.В. Маркетингова концепція формування продуктоорієнтованого інформаційного забезпечення підприємств: моногр. Рівне: вид. О. Зень, 2017. 291 с.

5.Окландер М., Губарєва Ю. Нейромаркетинг - теорія та практика впливу на підсвідомість споживача. Економіст. 2014. №11. C. 59-62.

6.Райс Эл., Райс Л. 22 закона создания брэнда. М., 2004. 65 с.

7.Дейнега О. В., Дейнега I. O. Маркетингові аспекти формування дизайну товару. Наукові записки Львівського університету бізнесу та права. 2010. № 4. С. 368-373.

8.Плишко Н. К. Особенности сенсомоторных реакций при изменении эмоционального состояния. Диагностика психического состояния в норме и патологии. Л., 1980. с. 126-134.

9.Jens B. The Proven Impact of Color On Consumer Behavior. URL: https://curatti.com/how-to-color-your-brand-color.

10. Овсійчук В. Історико-культурні аспекти семантики кольору. URL: http://www.koloristika.in.ua/t_kak.php. - (дата звернення: 14.11.2019р.).

11. Дейнега I.О. Маркетингові комунікації закладів вищої освіти на ринку освітніх послуг: моногр. Рівне: вид. О. Зень, $2018.278 \mathrm{c}$.

12. Закон України «Про освіту». URL: http://zakon.rada.gov.ua/laws/show/2145-19 (дата звернення: 14.11.2019).

13. Choosing the best color scheme for the websites you design. URL: https://1stwebdesigner.com/best-colors-for-websites/.

\section{References:}

1.Makhnusha, S. M. \& Kosolap, N. Y.E. (2011) The analysis of brand color as a tool for influencing the target audience of a brand. Marketvnh i menedzhment innovatsiv. № 2. pp. 95-104. (in Ukr.)

2.Skryhun, N. P., Semenenko, K. YU. \& Bilodidova, N. M. (2016) Color range in designing beer packaging as a key means of communication with the consumer. Naukovyy visnyk Khersons'koho derzhavnoho universytetu. Ser. : Ekonomichni nauky. Vol. 20 (2). pp 101-104. (in Ukr.)

3.Bozhkova, V. V. \& Nosonova, L. V. (2017) The role of printing advertising in promoting the products of machine-building enterprises. Naukovvv visnvk Uzhhorods'koho natsional'noho universytetu. Seriya : Mizhnarodni ekonomichni vidnosyny ta svitove hospodarstvo. Vol. 14 (1). pp 31-36. (in Ukr.)

4.Devneha, O.V. (2017) Marketvnhova kontseptsiva formuvannva produktooriventovanoho informatsivnoho zabezpechennva pidpryyemstv [Marketing concept of formation of product-oriented information support of enterprises]: monohr. Rivne: vyd. O. Zen'. (in Ukr.)

5.Oklander, M. \& Hubaryeva, YU. (2014) Neuromarketing - theory and practice of influence on the subconscious of the consumer. Ekonomist. №11. pp. 59-62. (in Ukr.)

6. Ravs, El. \& Ravs, L. (2004) 22 zakona sozdaniva brenda 222 brand creation lawl. M. (in Russ.)

7.Devneha, O. V. \& Devneha, I. O. (2010) Marketing aspects of product design formation. Naukovi zapysky L'vivs'koho universytetu biznesu ta prava. № 4. pp. 368-373. (in Ukr.)

8.Plishko, N. K. (1980) Features of sensorimotor reactions when changing the emotional state. Diagnostika psikhicheskogo sostovaniva v norme i patologii. L., pp. 126-134. (in Russ.)

9.Jens, B. The Proven Impact of Color On Consumer Behavior. available at: https://curatti.com/how-to-color-your-brand-color. (accessed 14.11. 2019).

10.Ovsiychuk, V. Historical and cultural aspects of color semantics. available at: http://www.koloristika.in.ua/t_kak.php. (accessed 14.11. 2019). (in Ukr.)

11.Devneha, I.O. (2018) Marketvnhovi komunikatsivi zakladiv vvshchovi osvity na rvnku osvitnikh posluh [Marketing communications of institutions of higher education in the market of educational services]: monohr. Rivne: vyd. O. Zen'.(in Ukr.)

12. Law of Ukraine «On Education» (2017). available at: http://zakon.rada.gov.ua/laws/show/2145-19 (accessed 14.11. 2019).

13.Choosing the best color scheme for the websites you design. available at:: https://1stwebdesigner.com/best-colors-forwebsites/(accessed 14.11. 2019).

УДК 331.522 .4

Дзямулич М.І., к.е.н., доцент, Н.М. Чиж, к.е.н., доцент

Луцький національний технічний університет

\section{ОСОБЛИВОСТІ ФУНКЦІОНУВАННЯ СИСТЕМИ НЕДЕРЖАВНИХ СТРАХОВИХ ПЕНСІЙНИХ ФОНДІВ В УКРАЇНІ}

У статті розглянуто особливості функціонування недержавних страхових пенсійних фондів в межах третього рівня системи пенсійного забезпечення в Україні в сучасних умовах розвитку національної економіки. Обгрунтовано необхідність вирішення актуальних проблем щодо розширення обсягів залучення населення до системи недержавного пенсійного страхування.

Ключові слова: пенсійне страхування, пенсійне забезпечення, недержавні пенсійні фонди, пенсійна система.

Dziamulych M., Chizh N.

\section{PECULIARITIES OF FUNCTIONING OF THE SYSTEM OF NON-STATE INSURANCE PENSION FUNDS IN UKRAINE}

